\title{
The effect of fermented pineapple peels in a diet that contains medicinal weeds on the performance broiler
}

\author{
W Ibrahim ${ }^{*}$, Nurhayati ${ }^{2}$, R Mutia $^{3}$ and $\mathrm{M} \mathrm{Hilmi}^{4}$ \\ ${ }^{1}$ Departement of Animal Husbandry, Faculty of Agriculture, University of Musi \\ Rawas \\ ${ }^{2}$ Departement of Nutrition and Feed Science, Faculty of Animal Science, Jambi \\ University. \\ ${ }^{3}$ Departement of Nutrition and Feed Science, Faculty of Animal Science, IPB \\ University \\ ${ }^{4}$ Study Program of Livestock Product Processing Technology, Politeknik Negeri \\ Banyuwangi
}

*Corresponding author: ib.ib48@yahoo.co.id

\begin{abstract}
This study aimed to determine the effect of using fermented pineapple peel in the ration containing medicinal weeds on broiler chicken performance. The experiment was designed into a completely randomized design (CRD) with five treatments and five replicates. Treatments consisted of $\mathrm{P0}=0 \%$ of fermented pineapple peels meal (FPPM) in ration containing $0 \%$ medicinal weed (MW), positive control). $\mathrm{P} 1=0 \%$ of fermented pineapple peels meal (FPPM) in the ration containing $2 \%$ medicinal weed (MW), negative control). P2 $=7.5 \%$ of FPPM in the ration containing $2 \%$ medicinal weed (MW). P3 $=15 \%$ of FPPM in the ration containing $2 \%$ medicinal weed (MW). P4 $=22,5 \%$ of FPPM in the ration containing $2 \%$ medicinal weed (MW). Two hundred two days of male broiler chicken were used in this study and kept for 42 days. The parameters were feed consumption, average daily weight gain, feed conversion ratio, slaughter weight. The observed data were analyzed by statistical product and service solution (SPSS 16.0), and Duncan's multiple range test tested significant effects among treatments. Results showed that the fermented pineapple peel meal up to $15 \%$ with other medicinal weeds was not influenced the broiler chicken performance.
\end{abstract}

\section{Introduction}

Pineapple peel is a waste pengo the rest of the pineapple fruit processing after being taken inside that number could reach $27 \%$ of pineapple production [4]. According to [5] pineapple peel containing water $81,72 \%$, crude fiber $20,87 \%$, carbohydrate $17,53 \%$, crude protein $4,41 \%$, and sugar reduction $13,65 \%$. [6] reported that the pineapple peel meal still has good nutritional value, dry matter $88.9503 \%$, ash $3.8257 \%$, crude fiber $27.0911 \%$, crude protein $8.7809 \%$, and fat $1.1544 \%$.

Pineapple peel also contains sugar reduction as much as $13.65 \%$ as an energy source. Sugar reduction is the sugar that has the skill for reduction; finally, the hydroxide compound's existence will be free and reactive [7] For example, sugar reduction is glucose and fructose. Higher sugar reduction of pineapple peels can provide an energy source for a broiler. However, the use of pineapple peels the limit of feed because of higher crude fiber $(19,69 \%)$ and low protein crude $(3.50 \%)$, High fiber foods resulting substance is hard to digest poultry to decrease the digestibility of nutrients, then the best 
thing to did it by way of fermentation. According to [8], yogurt is one of the fermentation; yogurt is defined as a food product derived from cow's milk with a shape such as porridge or ice cream, which is fermented milk with Lactobacillus bulgaricus and Streptococcus thermophillus. According to [9], fermented food material properties change due to the breakdown of ingredients; such changes could be $\mathrm{pH}$, moisture, aroma, and nutritional value changes. Increased crude protein and crude fiber decline in a material can be made by fermentation with yogurt containing the bacteria Lactobacillus bulgaricus. Utilization medicinal weeds as Mutiara grass (Hedyotis corymbosa or Oldenlandia corymbosa L), sidaguri (Sida cor difolia), bandotan (Ageratum conyzoides L), and patikan kebo (Euphorbia hirta L.) with containing medicinal weeds in ration given the best effect of broiler chicken.

The alternative strategy for feeding availability explored the waste from agriculture by-products such as pineapple. Pineapple's potential such as skin content in Jambi never optimally utilized, and source of feed for broiler potentially. Using skin pineapple by-products for poultry diets can be improved the profit income for farmers. The high sugar content of pineapple peels can be improved energy for the broiler. The limitation factor in pineapple peels in diets was high crude fiber $(19,69 \%)$ and low crude protein $(3.50 \%)$. The high crude fiber content showed low digestibility in poultry and decreased it with the biological process such as fermentation. One of the strategies to improve the protein content and lowered crude fiber by fermented use microorganisms such as yogurt was Bacillus sp. Exactly combine the Yoghurt also supplemented medicinal weed as a feed additive to maintain animal health. The medicinal weed was used in this combination, such as Mutiara grass (Hedyotis corymbosa Oldenlandia corymbosa or L), sidaguri (the eunuch cor difolia), bandotan (Ageratum conyzoides 1.), and patikan kebo (Euphorbia hirta 1.). Combining all of the medicinal weeds in feed can be improved the quality of feed by nutrient synergy effect in diets.

\section{Material and Method}

Two hundred two days male broiler chicken were cased in this study and kept in 25 cages $80 \mathrm{~cm} \times 80$ $\mathrm{cm} \times 100 \mathrm{~cm}$ each. Feed and drinking water were of ad libitum. The treatment was different feed, which contained fermented pineapple peel meal by Yoghurt as much of $3 \mathrm{ml} / \mathrm{kg}$ for 24 hours, a commercial ration BR1 on BR2, corn, polished, fish, and soybean meal. A feed additive was pearls grass: sidaguri: goatgrass: patikan kebo in 1: 2: $2: 2$. The treatment rations were composed of isoprotein and isoenergy. Feed composition and nutrient content treatment diets were shown in Table 1 .

The experiment was designed into a completely randomized design (CRD) with five treatments and five replicates [10]. The treatments were $\mathrm{P} 0:=0 \%$ of fermented pineapple peels meal (FPPM) in ration containing $0 \%$ medicinal weed (MW), positive control), $\mathrm{P} 1=0 \%$ of fermented pineapple peels meal (FPPM) in the ration containing $2 \%$ medicinal weed (MW), negative control), P2 $=7,5 \%$ of FPPM in the ration containing $2 \%$ medicinal weed (MW), P3 $=15 \%$ of FPPM in the ration containing $2 \%$ medicinal weed (MW), P4 $=22,5 \%$ of FPPM in the ration containing $2 \%$ medicinal weed (MW). Measurement variables were feed consumption, body weight, feed conversion, pancreas, proventriculus, ventriculus, liver, spleen, intestine weight, intestine large, intestine length, and $\mathrm{pH}$ of intestine.

\subsection{Statistical Analysis.}

The observed data were analyzed by statistical product and service solution (SPSS) 16.0, and Duncan's multiple range test tested significant effects among treatments.

\subsection{Fermented Pineapple peel meal}

Pineapple skin cleaned is then chopped, then dried in an oven at $60^{\circ} \mathrm{C}$. After the pineapple peels were dry, the shaving process is carried out. The addition of water to the pineapple peels flour in a ratio ( 2 : 1) or two liters of water and one $\mathrm{kg}$ of pineapple flour the addition of water is carried out to achieve a water content of $60-70 \%$. Steaming is carried out for 30 minutes, which aims to sterilize. After that, 
cooling was carried out for 10 minutes before the fermentation process with $3 \mathrm{ml} / \mathrm{kg}$ of yogurt for 24 hours.

Table 1. Feed composition and nutrient content treatment

\begin{tabular}{|c|c|c|c|c|c|}
\hline \multirow[t]{2}{*}{ Feed Materials } & \multicolumn{5}{|l|}{ treatment } \\
\hline & \multicolumn{2}{|l|}{ P0 } & P2 & P3 & $\mathrm{P} 4$ \\
\hline Commercial rations BR II & 50 & 50 & 50 & 50 & 50 \\
\hline corn & 15 & 15 & 13 & 5 & 5 \\
\hline Bran & 20 & 18 & 12.5 & 13 & 5.5 \\
\hline Soybean meal & 7 & 7 & 7 & 7 & 7 \\
\hline Fish flour & 8 & 8 & 8 & 8 & 8 \\
\hline Fermented pineapple skin & 0 & 0 & 7.5 & 15 & 22.5 \\
\hline Medicinal weed & 0 & 2 & 2 & 2 & 2 \\
\hline Total $(\%)$ & 100 & 100 & 100 & 100 & 100 \\
\hline \multicolumn{6}{|l|}{ nutritional composition ${ }^{* *}$} \\
\hline Dry material (\%) & 86.68 & 85.56 & 85.02 & 84.41 & 83.89 \\
\hline Organic material (\%) & 90.10 & 89.27 & 88.48 & 87.04 & 86.46 \\
\hline crude protein $(\%)$ & 20.85 & 20.19 & 20.25 & 20.53 & 20.52 \\
\hline crude fat $(\%)$ & 6.36 & 5.21 & 4.79 & 4.67 & 4.15 \\
\hline crude fiber $(\%)$ & 5.20 & 5.38 & 5.80 & 6.97 & 7.15 \\
\hline Calcium(\%) & 0.74 & 0.74 & 0.72 & 0.72 & 0.70 \\
\hline Phosphor (\%) & 0.59 & 0.53 & 0.52 & 0.50 & 0.49 \\
\hline Metabolic energy $(\mathrm{kcal} / \mathrm{kg})^{*}$ & 3003 & 2953 & 3027 & 3051 & 3142 \\
\hline
\end{tabular}

Note : P0: $=0 \%$ of fermented pineapple peels meal (FPPM) in ration containing $0 \%$ medicinal weed (MW), positive control), (P1) $0 \%$ of fermented pineapple peels meal (FPPM) in the ration containing $2 \%$ medicinal weed (MW), negative control), $\mathrm{P} 2=7,5 \%$ of FPPM in the ration containing $2 \%$ medicinal weed $(\mathrm{MW}), \mathrm{P} 3=$ $15 \%$ of FPPM in the ration containing $2 \%$ medicinal weed (MW), P4 $=22,5 \%$ of FPPM in the ration containing $2 \%$ medicinal weed (MW). P4 $=22.5 \%$.

* Results of the analysis of the Integrated Laboratory of the Faculty of Animal Science, Jambi University $(2014),{ }^{* *}$ Metabolic energy $=0.725 \times$ Gross Energy $($ NRC, 1994)

\subsection{The Process of flouring medicinal Weed meal}

Medicinal weeds rumput Mutiara, sidaguri, bandotan, and patikan kebo with already accumulated, minced, dried, and grind, flouring each weed stirred into one with Mutiara Grass: sidaguri : bandotan: patikan kebo $=1: 2: 2: 2$ and used as a feed additive in the ration.

\section{Results and Discussion}

\subsection{Treatment effect on feed consumption}

Analysis of variance showed that research on the use of fermented pineapple peels flour in the ration had a very significant effect $(\mathrm{P}<0.05)$ on ration consumption (Figure 1$)$. Duncan's multiple follow-up tests showed that ration consumption in treatment P0, P1, P2, and P3 had no significant effect (P> $0.05)$. This shows that the four groups of rations have the same quality and palatability, so that they do not affect livestock preference for rations. The ration consumption in P4 increases significantly. The increase in ration consumption in $\mathrm{P} 4$ showed that pineapple skin flour by $22.5 \%$ increased ration palatability so that the desire of livestock to consume the ration increased. Consumption decreases when livestock becomes full quickly, caused by bulky food substances such as fiber or water-rich foods. This study's ration consumption ranged from 2894.53-2970.95 $\mathrm{g} \mathrm{bird}^{-1}$ [12]. 


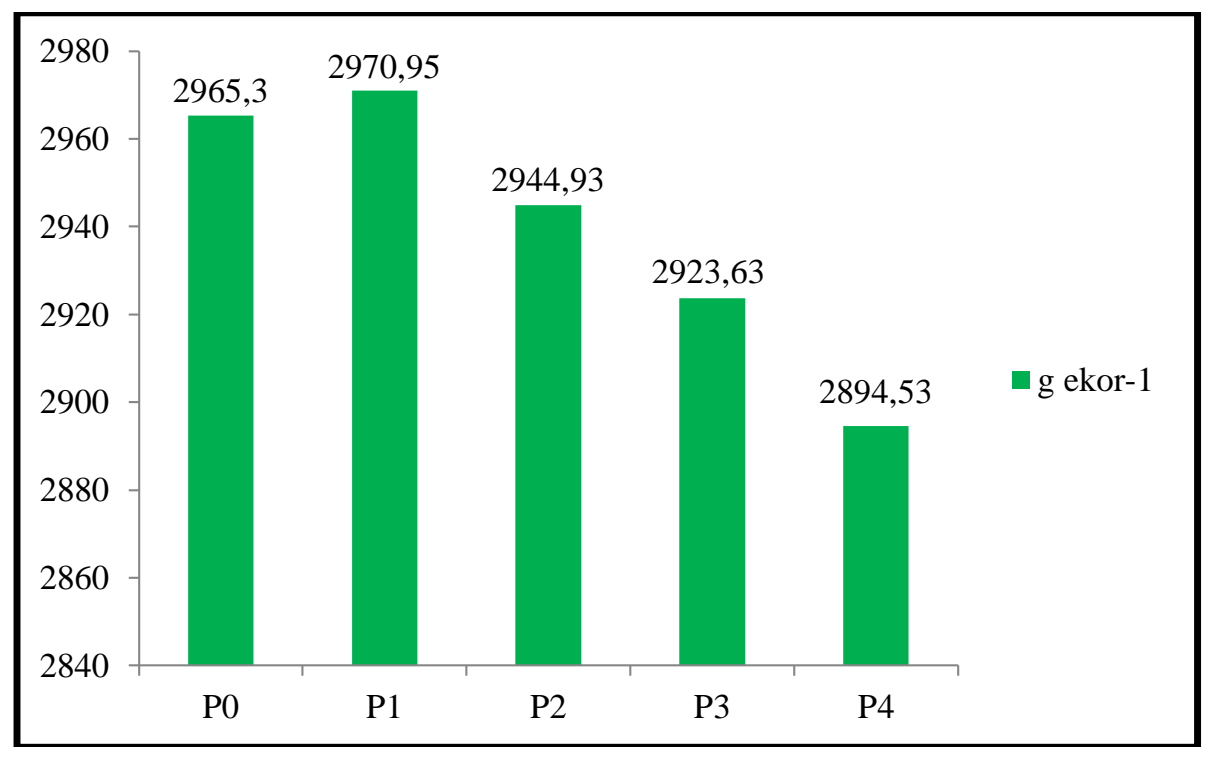

Figure 1. Treatment effect on feed Consumption

Based on the practical experience above, the Musi Rawas University Experimental Garden in Muara Beliti conducted an organic fertilizer with the main ingredient of factory crumb rubber waste plus vegetable waste, straw, cattle dung, and straw. Using organic decomposing bacteria (ODB), the soil that had initially lost its processing layer and even peeled off looks increasingly loose structure and turns black and productive.

This study tries to use the LP model to minimize costs. A single formulation of organic fertilizer (rubber factory waste) is obtained through this method for a minimal cost solution and compound organic fertilizer (rubber factory waste, straw, vegetable waste, and goat manure).

\subsection{Treatment effect on Weight Gain}

Analysis of variance showed that fermented pineapple peel meal in the feed affected body weight significantly $(\mathrm{P}<0.05)$ (Graph 2). Broiler chickens' bodyweight decreases significantly in the group that given pineapple skin flour by $22.5 \%$ compared with P0, P1, P2, and P3. It shows that in the P4 treatment using fermented pineapple skin flour $22.5 \%$, the level of chicken palatability to the ratio was reduced, so the food consumed was less, and consequently, the body weight gain decreased. The lower the palatability of the birds to the ration, the lower the body weight gain, and conversely, the higher the palatability of the ration, the higher the body weight. Poultry consuming feed containing fermented ingredients could affect organ weight [15-16]. Influencing the weight of the organs will also affect body weight gain Figure 2. Broiler weight gain is affected by the type of ration used, the environment, and the chicken strain. One of the factors that influence the broiler body weight gain is the consumption of feed and the fulfillment of the broiler's dietary requirements [17]. Livestock body weight is always directly proportional to ration consumption; the higher the weight, the higher the ration level [18]. 


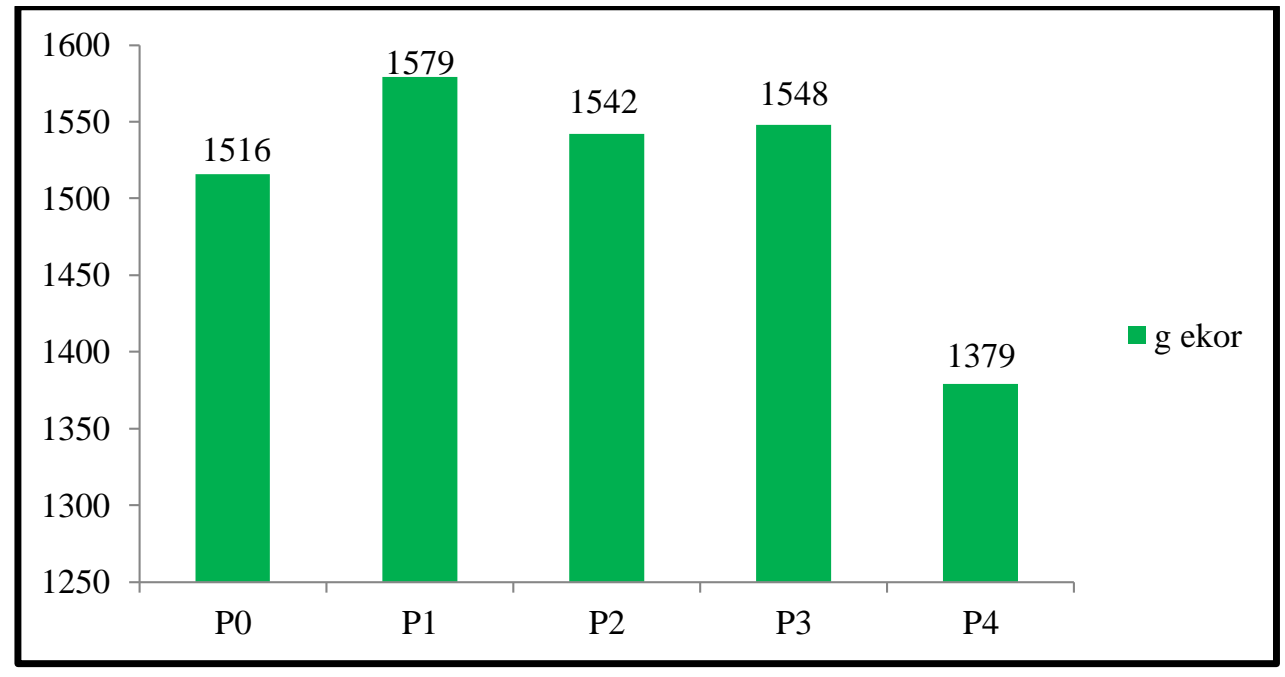

Figure 2. Treatment effect on Weight Gain

\subsection{Treatment effect on Feed Conversion}

Analysis of variance showed that the use of yogurt fermented pineapple peel powder had a significant effect on ration conversion $(\mathrm{P}<0.05)$ (Figure 3). Duncan's multiple follow-up tests of ration conversion in treatment $\mathrm{P} 0, \mathrm{P} 1, \mathrm{P} 2$, and $\mathrm{P} 3$ had no significant effect $(\mathrm{P}>0.05)$; ration conversion showed that there was a significant increase in the level of use of fermented pineapple peel flour of $22.5 \%$ compared to control feed that was not given skin flour. Fermented pineapple. Increasing in ration conversion in the $\mathrm{P} 4$ treatment was due to the increased palatability of the chickens to the ration and the decrease in body weight so that the conversion rate increased. The higher the ratio conversion rate, the lower the ratio use efficiency [11].

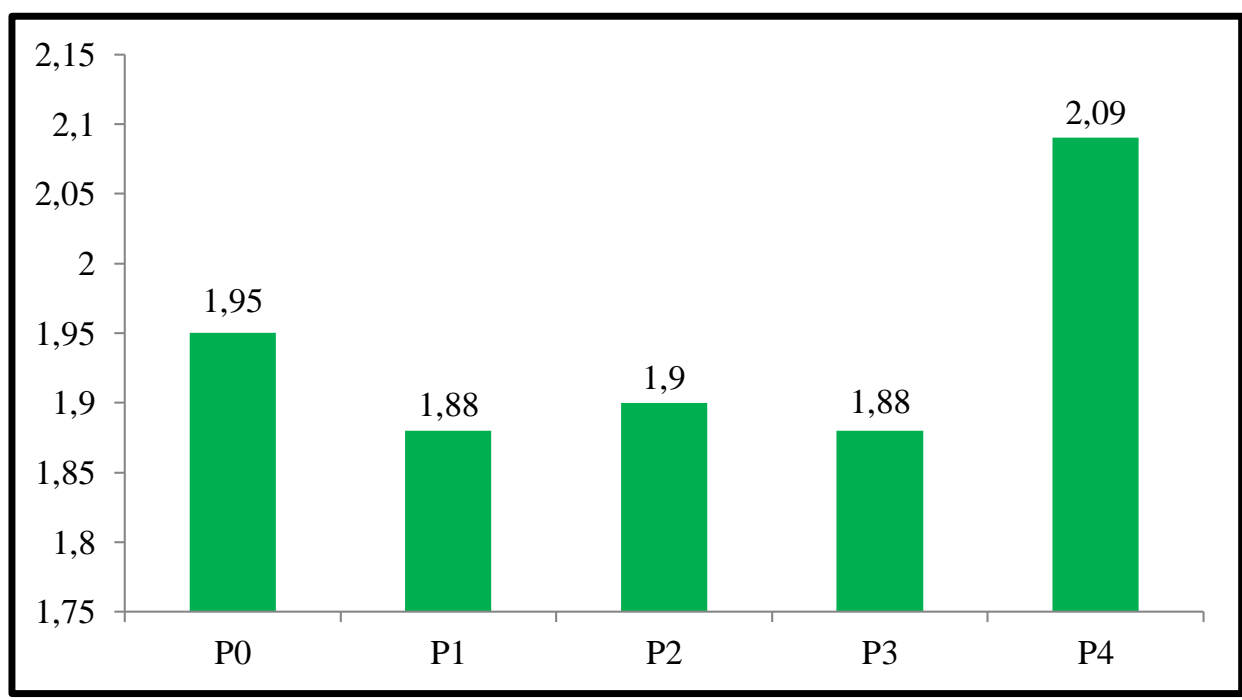

Figure 3. Treatment effect on feed Conversion

\subsection{Treatment effect on Mortality}

The mortality rate is one factor that can affect a farm business's success, especially broilers. During this study, the mortality rate was $2 \%$. The mortality rate for broilers is less than $3 \%$ [18]. If the mortality rate is more than $6 \%$, the farm's condition is taken seriously and must be paid attention to by the farmer. In this study, fermented yogurt pineapple peels flour worked well in maintaining animal 
health as humans are also encouraged to consume yogurt from an early age to maintain a healthy body. Medicinal weeds also play a useful role in medicinal weeds to maintain animal health, which means using fermented, pineapple peels flour and medicinal weeds as feed additives play a positive role in maintaining the health condition of livestock, especially broilers. Factors that influence livestock mortality include the type of chicken, the seeds used, feed, drinking water, temperature, and sanitation $[19\}$

\subsection{Effect of Treatment on slaughter Weight at 42 Days old chicken}

Analysis of the use of fermented pineapple peel flour with yogurt up to a level of $22.5 \%$ in the broiler ration gave a very significant effect $(\mathrm{P}<0.05)$ on the reduction in slaughter weight of broiler chickens (Figure 4). Slaughter weight on treatment $\mathrm{P} 0, \mathrm{P} 1, \mathrm{P} 2$, and $\mathrm{P} 3$ had no significant effect $(\mathrm{P}>0.05)$. This indicates a decrease in treatment $\mathrm{P} 4$ with the use of fermented pineapple peel flour as much as $22.5 \%$. $22.5 \%$ of the Slaughter weight given feed using fermented pineapple peel flour has a lower carcass weight than chickens fed without fermented pineapple peels. The lower the palatability of the birds to the ration, the lower the body weight gain, and conversely, the higher the palatability of the ration, the higher the body weight. With the low palatability of ration consumption, it is difficult for poultry's basic living needs to be fulfilled. Low protein consumption causes a small bodyweight because protein intake for growth is not sufficient so that chickens do not grow properly [22].

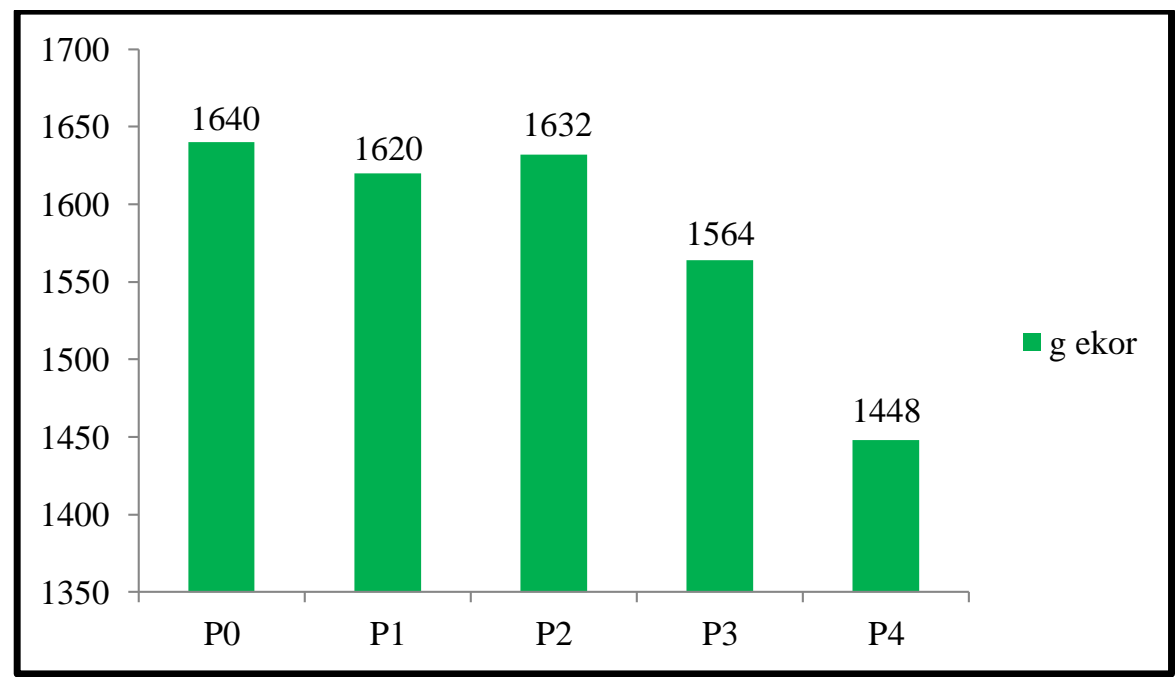

Figure 4. Treatment on slaughter Weight at 42 Days old chicken

\section{Conclusions}

The effect of adding fermented pineapple peel meal up to $15 \%$ with other medicinal weeds did not affect weight gain and ration consumption.

\section{References}

[1] Lubis, A.D. 1991. Utilization of Pineapple Waste as Animal Feed. Indonesian Animal Husbandry Magazine No 76.

[2] Jambi Province Central Bureau of Statistics. 2014. Jambi in Figures 2014. BPS Jambi Province, Jambi.

[3] Tahir, I. 2008. Study on the Use of Local Pineapple Fruit Waste (Ananas Comosus L) as Raw Materials for Making Nata, Papers of the XVIII National Chemistry Seminar, Department of Chemistry, Faculty of Mathematics and Natural Sciences UGM.

[4] Nurhayati, Nelwida, Berliana. 2014. Effect Of Different Level Of Yoghurt And Time Of Fermentation On In Vitro Digestibility Of Dry Matter, Organic Matter, Crude Protein And Crude Fibre Of Fermented Pineapple Peel. Bulletin Of Animal Science Vol 38 (3) : 182-188. 
[5] Wijana, S., Kumalaningsih, A. Setyowati, U. Efendi dan N. Hidayat. 1991. Optimizing the addition of pineapple skin flour and fermentation process to animal feed to improve nutritional quality. ARMP (Ministry of Agriculture). Brawijaya University. Malang.

[6] Nurhayati. 2013. Broiler chicken performance feed ration containing pineapple peel meal and supplemented by Yoghurt. Agripet 13 (02) : 15-20. .

[7] Lehninger. 1982. The basics of Biochemistry. Volume 1. translator Suhartono, MT, Erlangga. Jakarta.

[8] Sears, W dan Sears,W, RN. 1999. The Family Nutrition Book Everthyng You To Know About Feeding Your Children From Birth Through Adolescence. Litle, Brown USA.

[9] Winarno,F.G. 1997. Biofermentasidan Biosintesaprotein. Angkasa Publisher. bandung

[10] Ibrahim, W., Mutia, R., Nurhayati. 2015. Use of Fermented Pineapple Peel in the Ration Containing Medicinal Weeds on Fat and Cholesterol of Broiler Chicken. Agripet. Vol (14) no $1: 20-27$.

[11] Nurhayati, Nelwida, Berliana. 2014. Effect Of Different Level Of Yoghurt And Time Of Fermentation On In Vitro Digestibility Of Dry Matter, Organic Matter, Crude Protein And Crude Fibre Of Fermented Pineapple Peel. Bulletin Of Animal Science Vol 38 (3) : 182-188.

[12] Zuprizal. 2005. Nutrition and Poultry Feed (PTN 3302). Faculty of Animal Husbandry. Gadjah Mada University, Yogyakarta.

[13] Azizi BG, Sadeghi A, Karimi F, Abed. 2011. Effect of dietary energy and protein dilution and time of feed replacement from starter to grower on broiler chickens performance. Jurnal of Central Europeran Agricultural. 12 (1) : $44-52$.

[14] Sidadolog JHP and Yuwanta. 2011. (Effect of Protein- Energi Concentration in Feed on Body Weight Gain, Energy and Protein Efficiency in the Growth Period of Merawang Chicken. Vol $11(1): 15-22$

[15] Abul, K., K. Abbas, A.H. Lichtman, and S. Pillai. 2012. Cellular and molecular immunology. Seventh ed. Silver Sanders book aid international. USA.

[16] Ao, X., T.X. Zhon, H.J. Kim, S.M. Hong and I.H. Kim. 2011. Influence of fermented red ginseng extract on broiler and laying hens. Asian-Aust. J. Anim. Sci. 24: 993-1000.

[17] Fadilah. R. 2005. Combined managing commercial broiler farms. PT. agromedia. Library: Jakarta.

[18] Moreno, B.J., Gonzalez.,A.S. Lazaro.R. Mateos.G.G. 2009. Effect of dietary fiber and fat on performance and digestive traits of broiler from one twenty-one days of age. J. Poult sci. 88. $2562-2574$.

[19] Gultom SM, Suprtaman RdH, and Abun. 2013. the effect of energy and protein balance in rations on carcass weight and abdominal fat weight on broiler chicken 3-5 weeks. Journal Unpad. Vol. 1 (1) :1-5. 